\title{
Advocacy for a Universal Basic Income for the United States: My Story
}

\author{
Diane R. Pagen
}

\section{How I CAME To UBI}

I have been a social worker for the past 16 years in the United States. I've been an advocate for a Universal Basic Income-an agreed upon amount of income distributed to all with no means test of any kind-for about 13 of those years. It did not take long for me to go from well-intentioned but inexperienced social worker to brash disbeliever in the colonial model of charity and social service that is the flawed foundation of the U.S. welfare state. Prior to going to social work school, I already had ideas about "welfare" from conversations at home. My mother and my aunt, both of whom spent time on it-my mother in the late 1960s and my aunt in the 1980s-would talk about it. I overheard many conversations as a child between my mom and her friends, around the kitchen table in our "project" apartment in Queens, New York. The moms said that the monthly check was not enough and that welfare "workers" were uppity and obsessed with catching moms at home entertaining a man. As a kid, I overheard the moms use bad words when they talked about these welfare

D. R. Pagen $(\bowtie)$

Brooklyn, NY, USA

(C) The Author(s) 2020

R. K. Caputo and L. Liu (eds.), Political Activism and

Basic Income Guarantee, Exploring the Basic Income Guarantee, https://doi.org/10.1007/978-3-030-43904-0_6 
workers. We were instructed not to talk to the workers when they came to visit unannounced, their prying eyes scanning the rooms for men or for the new things they might buy the kids. When my mother remarried, the "workers" stopped visiting, and they were not spoken of again.

I'd gone to college in Puerto Rico, then came back to NYC to start the work life. Eventually, I decided to go to social work school. During social work school, I did what I thought helped poor people: volunteered in a shelter, at a food pantry. I donated a toy or a coat. Once I graduated, I worked: in a community counseling center; a special needs preschool; a hospital; three psychiatric wards; a shelter for homeless families; a rural child protection department; and a public school system. At the beginning of my career, I thought that the income, housing, and other programs that existed would help people. I grew tired after many disappointments, including inexplicable "cutoffs" from cash welfare, Food Stamp and other applications getting "lost"-the solution to which is to apply all over again-plus absent shelter directors, locked petty cash boxes whenever I needed to get someone some subway fare, and supervisors who got excited about holiday food "drives," toy "drives," and clothing "drives," but who balked at suggestions we demand increases in cash assistance or Food Stamps. We social workers knew well that means tests, compulsory job training programs and low monthly benefit amounts were not working. Means tests, for one, put obstacles between people and the means of survival. Why didn't we do something? Where, I wondered, were the activist social workers, the Bertha Capen Reynoldses, the Francis Perkinses, the Harry Hopkinses of the world? They sure weren't working where I worked. There were some notable efforts like the Social Welfare Action Alliance, started in 1985, for the most part social welfare organizations were not and are not activist.

At that stage, I was unaware of UBI. But then, while working on an education equity project at Fordham University, one day my boss, the late John Beam, saw me looking at Tyranny of Kindness (Funiciello 1993) on his bookshelf. "You should really read that," he said. I took it home. I read it in two days and called the author, Theresa Funiciello. I asked her what I could do to not become part of the problem, which she argues is in great measure the social welfare establishment. We met and soon after, she introduced me to Karl Widerquist and Michael Lewis, the founders of the U.S. Basic Income Guarantee Network (USBIG), and I read their book, Economics for Social Workers (Lewis and Widerquist 2002). She took me to my first USBIG Congress soon after and to my first Basic 
Income European Network conference. It was life altering-full of people thinking about why income was a right, thinking about income, and what happens when people don't have it. Some were practical and some were more abstract. There were people who wanted people to be free more than anything, and people who wanted to not be poor more than anything. I got to meet Jay Hammond, the Alaska governor who created the Alaska Permanent Fund, a universal payment to all residents of Alaska. I plunged into learning as much as I could about UBI while doing social work jobs.

Over time, and based on what I see in my social work, I have come to believe that no one's survival should depend on the actions and decisions of another. As much as I want to help people, I don't want anyone's life to depend on me. Having a decent and adequate income distribution does not make kindness unnecessary, it just makes it that our basic needs get met, and sustains life. Life with an assured consistent income will still be really hard, because life is hard. Human warmth, generosity and acts of kindness will always be needed to get us to the next level.

For the first few years, I worked with Theresa Funiciello's think tank and advocacy group, Social Agenda, on her campaign to compensate unpaid caregivers of adults and children via a federal caregiver tax credit. I started reaching out to charity organizations and pointing out the problems with non-cash aid, and the obstacles woven into means tests (the practice of verifying if people are poor as they claim) that delayed getting income to people. I began to write about social work from the point of view of belief in income transfers first, social services maybe. I continued to write once I'd had to return to social work. Some of my articles, such as an opinion piece that was critical of "healthy food financing initiatives" and funding nutrition education for poor families, annoyed some people, like my supervisor at the time in an NYC public hospital (Pagen 2010), who felt that Democrats should not criticize other Democrats in public forums, even when the policy solutions offered up contained no cash for poor people (I was an Independent; but his assumption was that all social workers are Democrats).

I also taught social policy, making sure we dedicated a unit to Nixon's Family Assistance Plan and to an analysis of the history of income maintenance. We discussed whether people could be fully helped without cash, providing only social services. Not every student agreed that income could replace social work, but we agreed often that while social work may be the answer to other problems, it could not remedy the desperation and 
health problems caused by a lack of income. We discussed whether withholding income is a violation of one's right to live. Many of my students came to agree that in a modern society where people no longer have land and time to grow food and make their own supplies, that withholding income is a violation of everyone's right to live.

When I was doing internships for my social work degree, most days were spent working with clients in despair over their economic problems. This led me to believe that there was something profoundly wrong with the U.S. welfare system. In Tyranny of Kindness, Theresa had argued that welfare bureaucrats were perpetuating poverty through the design of our national "welfare" program, at the time called Aid to Families with Dependent Children. She also contended that big charities, the shelter system, and the food pantries and soup kitchens used money that would be better spent on income maintenance, and forced poor people to piece together survival from stuff with a lot of conditions attached and barely any cash. Cash, she wrote, was the one thing mothers on welfare needed. Chapter nine of Theresa's book was about Universal Basic Income. Her book predates the current rebirth of UBI by about 25 years.

During the time Theresa hired me to work on research and outreach around unpaid caregiving, there were no courses in my social work school dedicated to examining Universal Basic Income. UBI made waves in the 1960s, and in the 1970s, a national UBI proposal passed the U.S. House of Representatives twice. In 1964, a panel of U.S. business leaders recommended a UBI in a document, the Triple Revolution; in 1968, a President's Commission on Income Maintenance Programs was examining universal income transfers as a new policy. As far back as the 1910s, women fought for cash transfers to mothers at the state level and were victorious in establishing Mothers' Pensions in some states, temporarily winning the argument that childrearing is work and requires cash not charity. Though a good deal of attention was paid to national hero and human rights leader Rev. Dr. Martin Luther King, Jr. in the social work curriculum, his support for UBI, or Guaranteed Minimum Income (King 1967), went unmentioned. Richard Nixon's Family Assistance Plan gets a few sentences in social work textbooks, but if you blinked you'd miss them. Part of how I came to UBI was seeing that despite its compelling simplicity and history, it was being ignored in the social work world. It largely still is, and that is something we social workers need to change. In 1964, the National Association of Social Workers officially endorsed a 
Guaranteed Annual Income. It is time for social work entities to endorse it again.

The proposals for a national UBI are more reasonable and adequate than our main "welfare" program, now known as called Temporary Assistance for Needy Families (TANF). TANF monthly payments are pegged in most states at three to four times less cash aid than the suggested cash aid in current UBI proposals. $\$ 1000$ per month seems like a sensible starting point as long as there is a commitment to peg the benefit to the cost of living and assure that its purchasing power will therefore be maintained. Other proposals suggest $\$ 2000$ per adult and an amount per child. For the reason of more cash alone, a UBI is vastly more adequate for meeting basic human needs than TANF. Contrary to popular belief, a UBI is not going to make the poor worse off financially.

The best social policy, wrote David Gil in Unraveling Social Policy, has adequacy as a fundamental characteristic (Gil 1981). Yet our social welfare programs are designed with payments set too low to meet basic human needs, and have been for decades. The redesign of AFDC to become TANF only worsened the inadequacy of the monthly cash assistance and began a systematic reduction of numbers of poor people enrolled. Now, TANF is also inadequate in that states enroll far fewer people than are eligible. Without income support, poor Americans are forced to consume costly services, such as medical care, early educational interventions, food from the discard market (leftovers and non-sellable food), and get only piecemeal help from charities when these organizations do used coat giveaways in winter and free turkeys at Thanksgiving. My career is full of memories of toy, food, and coat giveaways gone awry-children in tears when "Santa" ran out of presents; when people who lined up for used coats could not find their size; a form clients had to sign at Catholic Charities saying they agreed they would only use the pantry once a month, when they needed to come every week because Food Stamp payments are so low. The evidence that only direct and adequate income transfers could effectively help people live just piled up in front of me.

There were more events over time that solidified my belief in consistent, adequate, and universal income transfers. For one, I questioned the objection that distribution of income is socialism. That's a go-to accusation that people against UBI fling out, but it's baseless. Income distribution is not socialism, its what permits us to preserve our ability to be social while functioning in a market economy. I questioned that I was only worth something if producing something someone else wanted to 
pay me for. I also saw the reasonableness of UBI instead of means tested programs, because means tests seemed to create hazards: missed meals, missed rent, illness and missed opportunities. Food Stamps were cut by mistake, often, arbitrarily, for dozens of my clients every year. Terrible news events, like the two toddlers, Scylee and Ibanez Ambrose, who were scalded to death by a faulty radiator in an NYC shelter before Christmas of 2016, because the shelter operator didn't do needed repairs. The thousands of people of upstate New York, who in 2011 lost jobs, clothes, food, cars, and homes, when the region flooded after Hurricane Irene, who were then sent to line up for donated food and clothes in the blazing heat of August. There was the mother and father I met who needed to drive 70 miles to pick up his paycheck and had to suffer through an hour of questions to get gas money from our social services unit. To get the help approved, I had to calculate the dollar amount so close that for the whole trip, the parents worried that they would run out of gas. The story of Kimberly Dobbie of Maine, where only 19 out of every 100 families get TANF cash at all (CBPP 2018), who in 2017 was homeless and with two children, is another that highlights the dangers of having an unstable income. Short of money, she accepted free meals from a man who later murdered her.

The logical policy conclusion from all this is that a benefit that does not require means tests, nor conditions, and distributes income instead of goods or services will meet the basic human needs of people more consistently, more adequately, and more efficiently. This is how Universal Basic Income works. There are many ideas about how our UBI should be designed, whether it should stack on top of existing programs, and what human needs should have separate guarantees, like a housing guarantee, which I support. We should welcome all these questions and come enthusiastically to the table with our different concerns and proposals. We cannot let differences of vision on how we should design our national UBI stop us from creating one. That is what the preservers of our status quo want, to deter us from establishing an income floor as a matter of right. But there is too much at stake to get sidelined over small differences.

If Scylee and Ibanez's parents had had a UBI, they could have chosen a safer place to live than the shelter they were in the Bronx, NYC. They would have had a combined household income of $\$ 2000$ a month, plus whatever they made through jobs. Having no income meant that the only way they could ever qualify for a low rent apartment was to survive the shelters first. While public assistance would not distribute an adequate 
income to the Ambrose family, New York City paid the operator of the shelter they stayed in, Bushwick Economic Development Corporation, $\$ 116$ million between 2004 and 2016 (Checkbooknyc.com, 2019). After it killed their children, BEDC barely missed a payment for their shelter "services" and is still a recipient of million dollar city shelter contracts today. Scylee and Ambrose's parent buried them in Maine.

If the people of upstate New York had had a UBI during the flooding in 2011, they wouldn't have had to drive to other counties, spending gas money they couldn't afford, to go wait on lines for hours to get food donations, and submit to means tests to prove they needed cash.

\section{“Welfare" and the VAlue of UnPaid Labor}

During the 1980s, prior to her work to create a fully refundable Caregiver Tax Credit, Theresa Funiciello had been introduced to the U.S. welfare system AFDC when she turned to it as a single mother. By the time I met her, she had both personal knowledge of welfare's faults and cruelties, and knowledge from her activism as part of the Downtown Welfare Advocates Center (DWAC) to raise the NYS monthly cash benefit.

Theresa made me follow my intuition when something seemed to make no sense from both a policy perspective and a human one. If TANF welfare (formerly AFDC which was redesigned and re-named Temporary Assistance for Needy Families in 1996) was making its recipients' lives qualitatively worse, social workers should not blindly be confident that we were "doing good." She said that I needed to analyze the programs. I found that in every state, TANF payments were inadequate; and enrollments were trending down. This was due to churning (the phenomenon of arbitrarily removing people from the welfare rolls before you are sure they are ineligible, then signing them back up later) as well as people not signing up at all.

Then and now, people are suffering the effects of having inadequate or no income. The cash portion of a parent's TANF payment has lost $40 \%$ of its purchasing power since 1981; across the country, only 23 out of every 100 qualified poor families are enrolled (CBPP 2018).

TANF administrators in most states have a well-funded enterprise flush with federal dollars. Due to the lack of enrolled people relative to the available dollars, large piles of millions in federal unspent funds accumulate, $\$ 3.1$ billion nationwide in 2018 (Administration for Children and Families 2018). The state TANF administrators then use that money for 
stuff that often has nothing to do with helping poor people. The budget phenomenon of a state using TANF funds to pay for a line item that has always been a state budget item, in order to free up state funds for non-poverty uses, is called supplantation. It's unethical, and a reason that precarity here is on the rise. There is a perverse incentive to drive down the numbers of people on the rolls so as to have more unspent dollars left over.

No one realized it, but with the Caregiver Credit Campaign, Theresa was working on the creation of a Universal Basic Income that would protect women and children from the abuses of the welfare system. It would acknowledge and reward (mostly) women's unpaid caregiving labor while sidestepping the whole welfare-to-work debate over whether poor women also deserved recognition for their caregiving of their own childrena recognition that the stay at home moms of the upper classes already received. I passed out flyers and spoke at schools, at churches, and at community centers about the need to convert the Child Tax Credit to a fully refundable federal caregiver credit. Some established social services people reacted negatively when I presented our proposal. Perhaps they feared that social services agencies that provided respite services would lose some funding if the caregivers got money in their own pockets. I still recall how Carol Levine of the United Hospital Fund refused to sign our petition asking for Congress to create a fully refundable federal Caregiver Tax Credit when I approached her after her talk at Fordham University about ten years ago. "That's a waste of my fucking time," she said as she blew past me. "When they treat you badly, it means you are doing something right," Theresa once said.

\section{UNIVERSAL Basic INCOME as SUPERIOR tO the Current U.S. SAFETY NeT}

Dollar increases to TANF benefits are infrequent and tiny. An increase in Maine's TANF benefit in 2017, while surely welcome by people enrolled, amounted to only about $\$ 25$ a week additional cash to a family with an income below the poverty line. It was the first time the state has raised that benefit in a decade. New Jersey raised its TANF benefit in July 2017 by a mere $\$ 10$ per person per month. Texas raised its benefit by $\$ 4$. South Carolina by $\$ 3$. Most states' benefits are pegged below $30 \%$ of the federal poverty line (CBPP 2018), with some shockingly low, such as Alabama, pegged at $\$ 215$ a month for a family of three, or 12 percent of the U.S. 
poverty line. At the same time, the most exploitative aspect of the state TANF programs-forced work requirements-has been left untouched, so recipients are in effect working for wages as low as $\$ 1.50$ an hour.

Despite the ongoing contributions of excellent researchers, TANF's failings and dubious management of billions of dollars, and states' severely low caseloads never attract sustained media attention. Here and there, a story of TANF mismanagement will be in a local newspaper, but the dots rarely get connected to conclude that the mismanagement episodes are made possible by the faulty design and misplaced priorities of the national program. Peter Germanis, an expert who writes under the name Peter the Citizen, often responds to policymakers and legislators who claim TANF is a successful policy that should be a model for other anti-poverty programs. He has said TANF is "a slush fund with zero accountability" (Peter Germanis, phone communication to author, July 2013).

He prolifically documents states' TANF administration and use to push for reform and to warn against designing other anti-poverty programs as block grants. For example, he shows how some states like Ohio track down poor people who are not receiving TANF and are also employed. The state offers these poor people who are already employed a "benefit" of $\$ 5$ a month. If the person says yes, the state "enrolls" them and includes that person in their state's numbers of employed TANF recipients, subsequently claiming that these recipients are working because Ohio TANF got them a job. It's fiscally and morally dishonest, a lie that keeps alive the belief that TANF work requirements are effective against poverty, and it keeps the big federal block grants coming. Pro-Welfare Reform think tank analysts then write papers that contend that TANF's work requirements are getting jobs for poor people.

Between October 2016 and December 2017, the number of people enrolled in TANF nationwide went from 2,717,280 to 2,355,205. Nobody knows where the 362,075 people went (Administration for Children and Families 2018), or how they are surviving. They may be some of the people now living in tent cities in Los Angeles, Philadelphia, and in my own city of New York, where homeless people have set up tents in the tall grasses of Marine Park, Brooklyn, as well as in dark corners of Manhattan. New York only enrolls 42 of every eligible 100 families in its TANF program, even though every year it has plenty of money to help 100 out of 100 .

With no income, lives are upended. People die (Fig. 6.1). 


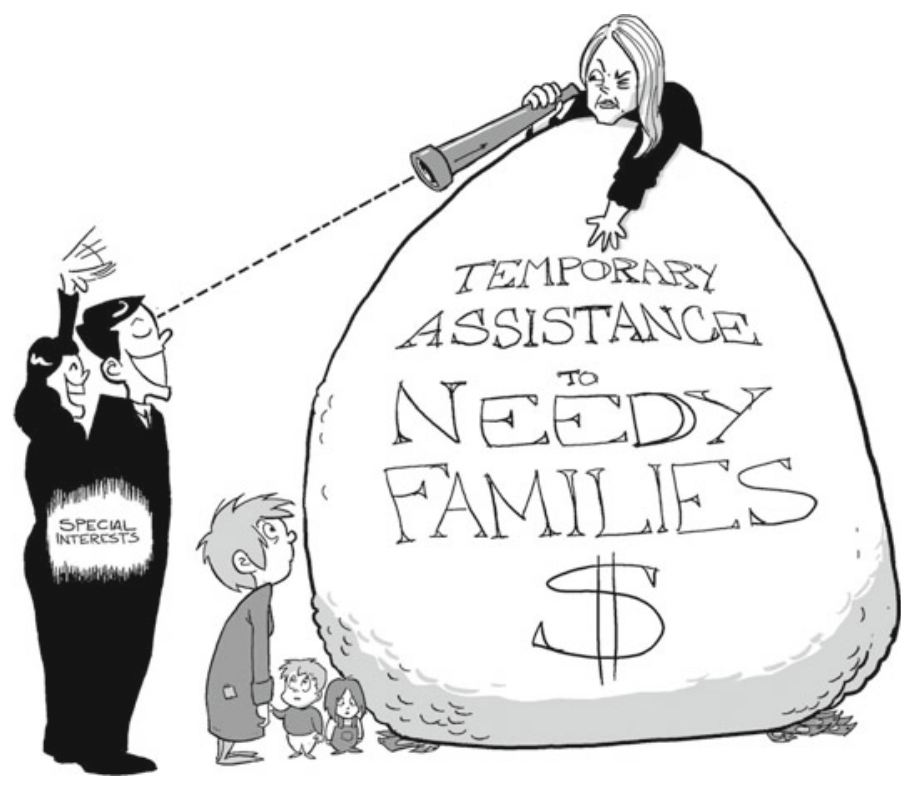

Fig. 6.1 TANF (Source Illustration by Nathan Schreiber; Owned by Author)

Peter the Citizen, pointed out that the U.S. Department of Health and Human Services was awarded the undesirable "Golden Fleece Award" for July 2019 by Congressman French Hill of Arkansas for its TANF policy. The not so coveted award was created in 1975 as a mechanism to report on "the most frivolous and wasteful uses of hardworking taxpayers' dollars" (Germanis 2019).

In the 1800s, minimal cash aid and forced work kept the Irish, English, and the colonial workhouses full-it was either enter the workhouse, or welfare administrators in the United Kingdom would allow those who remained outside to starve. The policy worked, driving frightened and starving peasants to these awful places in droves. In the 1900s, local poormasters in U.S. cities and towns wielded the power to eat or starve, live or die, by withholding bread vouchers and heat vouchers on a whim, unaccountable to anyone. In 1938, the infamous cruelty of one of these poormasters ended in his death inside a Hoboken, NJ relief office (Metz 2017). 
Modern welfare policy operates much the same as old times. The "workhouse" is no longer a physical building, but a series of obligations and erratic delivery of services and income that function a lot like the workhouse did. We deny eventual real housing and cash transfers to those who won't agree to spend time in a shelter first, or who won't agree to an exploitative "work opportunity." Everyone, from a shelter operator, to a frontline caseworker, to a therapist the poor person is obligated to see, makes money off of client. If the client loses their temper out of despair while taking part in these services, they get sent to compulsory "anger management."

No one considers that the system drives people to despair. The lack of adequate cash welfare is an intentional policy whose purpose is to keep people in a psychological prison, desperate to meet their own need for minimal food and warmth. If they have children, the desperation is that much more acute.

Although modern-day recipients of welfare receive TANF outside of an institution, TANF's behavior requirements, mostly non-cash aid, frequent case closings, and frequent check-ins, its infamously rude office workers, compulsory work, and public denigration of recipients make it that in practice, TANF retains many aspects of colonial aid systems.

\section{ADVOCACY}

It doesn't get any easier. For example, at a conference in Washington, DC, where Cindy Gillespie, a department head of Arkansas Health and Human Services, was speaking on a panel about "increasing health outcomes" in low-income communities in that state, I got up to share some data that wasn't being shared. Seeing a representative from Arkansas on the panel lineup stunned me, since Arkansas bungled health care for thousands of poor Arkansans recently by requiring Medicaid users to submit documentation via the internet that they were "working" or "job searching." So I didn't have much confidence in her oversight of Arkansas's TANF federal block grant. Arkansas TANF is in the top ten of the lowest-paying, most exploitative, and worst performing TANF programs in the United States. It enrolls only 5 out of every 100 families in Arkansas poor enough to qualify while its monthly welfare benefit for enrollees is pegged at $12 \%$ of the US poverty line. Despite this, Arkansas continues to accept milliondollar federal block grants every year in the name of "helping" its poor residents. 
During the Q and A session after the panel discussion, I asked Gillespie, "Since there is no question that low income is a predictor of poor health, how do you expect poor people in your state to be healthy with a monthly benefit pegged at only $\$ 200$ dollars, more or less?" You could have heard a pin drop in that room of 200 people, as she sat at a loss for words next to the other panelists. They, too, looked like they wanted to know. Since I had the floor, I also asked Gillespie why she didn't double or triple the Arkansas monthly cash benefit by spending some of the pot of federal welfare funds she had amassed in the category of "unspent and unobligated funds." At that point, that amounted to \$31 million. She said that she was "open to trying everything." "You're the commissioner," I said, "so you can do it." She didn't say she couldn't. I have been emailing her for over one year since that conference, to follow up on her being "open" to raising the cash benefit to Arkansans. She hasn't gotten back to me.

My activism started with my social work trying to make sense of our national welfare program and trying to unknot the mistakes that caused my clients' cash or childcare vouchers to be cut. Sometimes, my homeless families who got TANF or Food Stamps would get approved for rent assistance and move into an apartment. The next month, they'd find their cash portion reduced by the amount of rent aid they'd been approved for. To think that reduction was okay, you'd have to believe that moving from one place to another made human beings need to eat less.

I realized how states were (a) making cash under TANF harder and harder to get and (b) keeping the monthly benefits at miniscule levels in most states. When I further analyzed the data and saw how states were hoarding large portions of their annual block grants while their numbers of poor people grew, I became more active in movements promoting unconditional cash transfers. We needed to win a supplement that was non-means tested, fully refundable so the very poorest residents would get the benefit as cash and go to a majority block of eligible people. So that any attempt to remove it after we finally won it would be folly. Theresa Funiciello conceived this as a Caregiver Tax Credit, an expansion of the existing federal Child Tax Credit which included unpaid caregivers of adults as well as parents and other unpaid caregivers of children. This would have amounted to a universal cash payment, recurring and adequate, or basically a UBI.

I worked on the Caregiver Credit with Theresa from 2002 to 2008, speaking to groups about the economic value of unpaid caregiving, 
approaching senators in the hallways of the Congressional buildings, and writing on the topic. Theresa and I co-wrote a comic book, The Adventures of Carrie Giver, the Cost of Caring (Funiciello and Pagen 2006), and delivered copies to every member of Congress. She conceived a heroine who could be in two places at once and had superpowers to help others-much like many mothers and other unpaid caregivers. The Hill did an article on the comic and the Caregiver Credit Campaign. Theresa's strategy to get the Caregiver Credit was to focus on the unpaid caregivers of ill or aging adults as well as mothers caring for their own childrenconstituent groups these same legislators viewed as worthy and noble.

By 2008, our funding at the Caregiver Credit Campaign had dwindled and there was no more money to pay me. I got a job working for Health and Hospitals Corporation with children in East Harlem. I kept working on Universal Basic Income stuff as much as I could when I was not "earning a living." Eventually, I left my social work job at the hospital and moved upstate for a year, to get some quiet in the country. I worked in Delaware County, New York, for a year in their social services department. As a Child Protection caseworker, I visited lots of families uninvited. Most all of them were fine parents stuck in the mayhem of poverty, including the terrible TANF program and other inadequate forms of aid.

The next year, I moved back to New York City, where another life event added to my reasons for believing in UBI. In January 2012, I was in a new relationship and had moved back to NYC because after a few months of dating, we wanted to live together. What should have been a very healthy time in both our lives turned tense when, after a couple of months of a slow job search, I had not found full-time work yet. I was not bringing home any income and was turned down for unemployment for several months while UI verified and re-verified my eligibility. My partner would swing from being very enthusiastic and supportive to saying mean things I'd as soon forget. Accusations that I was not trying hard enough to find work flew, until I found some work. Then, accusations that I wasn't trying hard enough to keep a bad job flew when those bad jobs didn't work out. In one, I was fired from a temp job in a hospital psych ward after sounding the alarm that the caseload was too high to do a thorough job. Lack of money poisoned our mental space. It officially ended when I refused to turn down a fellowship I had been awarded to go write for a week; he said that since I was between temp jobs, I should stay home and prioritize getting another. I decided I should prioritize real work that drew on my real talents, whether paid or not, and that doing so 
for one week was not frivolous. It wasn't the only reason, but strain over money and "work" did not help. Furthermore, the unpaid work I did every day, on cooking and cleaning, was not viewed as work-only paid work "counted." This devaluing is at the heart of the American values system rammed down all our throats. The implication that I did not deserve any joy or reward, and even that there was something wrong with me because I was "out of work," is very consistent with the scarcity thinking we have bought into, and it is ruining humans and human relationships. Systems theory says when people are torn apart from one another, by extension society is torn apart.

\section{Basic Income Action}

2014 and 2015, I continued to educate myself on poverty policy, taught Introduction to Social Policy classes at Rutgers School of Social Work, accompanied my social work clients to welfare offices and housing interviews, and wrote about what I saw. That year, after the USBIG Congress, we held a meeting on Atlantic Avenue in Brooklyn, to talk about turning more toward activism and getting legislators on board for UBI. We agreed that we had to get really politically active, or we'd just be talking to each other for the rest of our days. We formed an initial policy advocacy group, Basic Income Action, comprising five people who were already working on UBI. We started to build a database of interested people and support the eventual growth of local activist groups who could do actions locally, hold educational forums, write, and approach community leaders and politicians about UBI. Karl Widerquist and Michael A. Lewis, the founders of USBIG, helped find others in our community who could be part of Basic Income Action. I signed up. The launch of Basic Income Action was intended to provide long-term technical assistance for the locals who had the time and the will to do events. We set up a website with FAQs, history of UBI, and links to other webpages, particularly USBIG and its internet archive of research papers published throughout the years.

Basic Income Action held a launch event in Washington, DC. People signed up at the website, so we could let people in one geographic area know about others in their area who wanted to do local actions and events around UBI. We fundraised a few thousand dollars, which we were able to parse out to help some regional supporters hold some community events. We wrote a grant to get funded, but were turned down. Despite having 
no money, we were able to support the creation of local Basic Income groups in Seattle, Minneapolis, and New York City. Some other groups formed but fizzled. I and a few other New York-based UBI advocates formed Basic Income NYC the following year. During this time, I worked at then left several social work jobs.

\section{Basic Income NYC}

Basic Income NYC started holding monthly events. Our first meeting in 2016 was at 330 7th avenue, in a space one of our group, Jude Thomas, got on loan. We planned to host activities including semi-monthly to monthly gatherings that we called Basic Income Movie Nights, where we would do education around UBI and recruit new supporters. The original group, though it has changed over time, was me, Jude Thomas, Joel Cabrera, Helen Strom, and Jacob Sparks. Jude is a performer/singer; Joel was a businessperson, Helen was an anti-poverty activist, and Jacob was a professor of philosophy. Later on, David Traynor, a teacher and activist from Ireland, joined us, and so did Ben Vient, a journalist. Wendy O'Shields, an activist for the rights of homeless people who is also a graphic artist, helped with designing flyers for our events. We selected videos about UBI that we could use as a jumping-off point for discussion for the nights. We also had guest speakers, and every month we tried to get more people to join us (Figs. 6.2, 6.3 and 6.4).

We created a video in Downtown Brooklyn, called, What Would You Do? and interviewed people, asking them the question, what would you do with your $\$ 1000$ a month Universal Basic Income? We got a space loaned every month in lower Manhattan at the Urban Justice Center. When not at my social work job, I wrote opinion pieces about poverty and pieces critical of U.S. safety net programs. One, Our Grenfell: Slow Death of the Poor, was published shortly after the disastrous fire that killed 72 people in a low-income high rise in London (Pagen 2017) (Fig. 6.4).

Around 2016, people started to write more about UBI in mainstream magazines, and my phone would ring more with calls from journalists and researchers. No one was more surprised than me. In 2017, Sarah Glazer called me for her CQ Researcher article, "UBI: Would Cash Payments Relieve Job Losses due to Automation?" (Glazer 2017). A few months later, Tony Mecia of The Washington Examiner called me for his article, "The Case for Free Money" (2018). I still went to welfare offices to try to get women their cash or Food Stamps back when they were cut. I tracked 


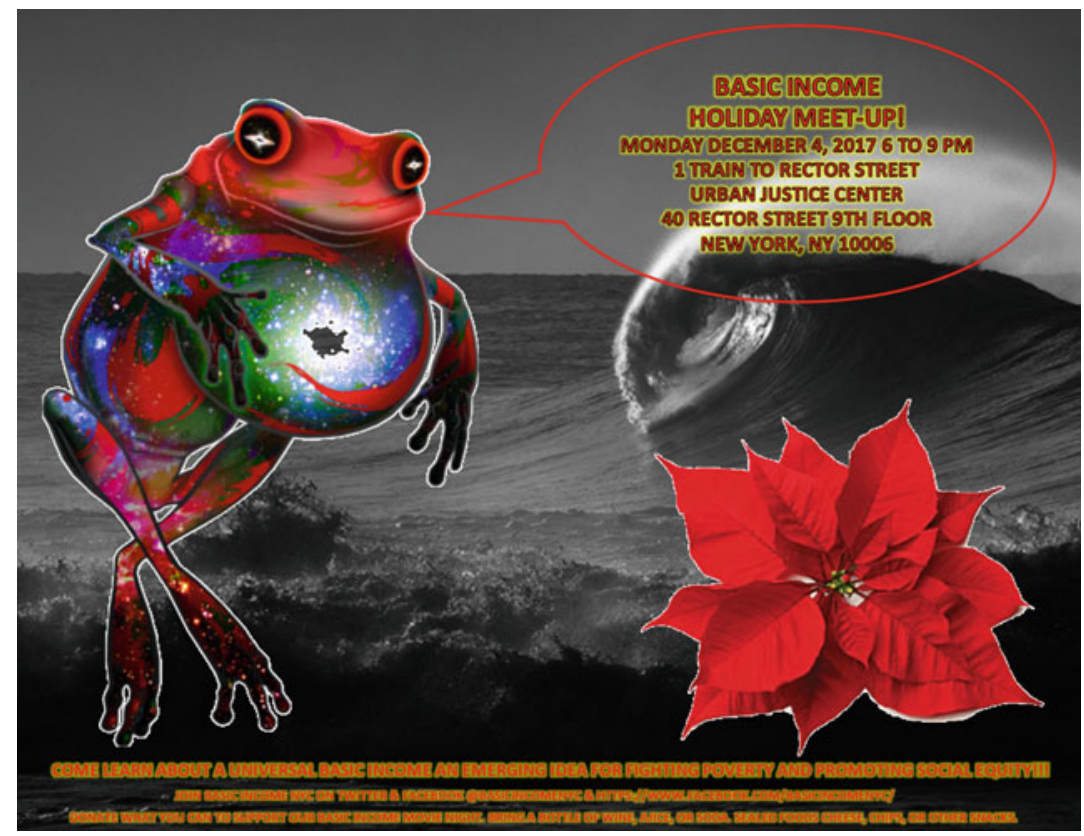

Fig. 6.2 Basic Income Movie Night flyer (Source Image by Wendy O'Shields; Owned by Author)

down cribs for new moms when charities wouldn't give them. I leaned on landlords to take rent vouchers for my clients and I wrote to legislators to get them interested in righting the wrongs of the 1996 "welfare law" which created TANF-officially known as the unpronounceable acronym PRWORA (Public Law 104-193). I worked on policy analysis while helping plan our Basic Income Movie Nights. By 2017, I had built my name in the local movement through our regular Basic Income Movie Nights.

In December 2017, we had a particularly festive Movie Night, complete with UBI videos, a table of food, Christmas lights, beer, and a violin duo, as well as mulled wine. A few minutes after we got started, a few guests walked in unannounced. We met later in the "mingle" break and were talking most of the night. I asked them why they decided to come. Their boss had sent them, they said. His name was Andrew Yang.

I invited Andrew Yang to our February 2018 Basic Income Movie Night to be our surprise guest. Nobody around the table knew who he 


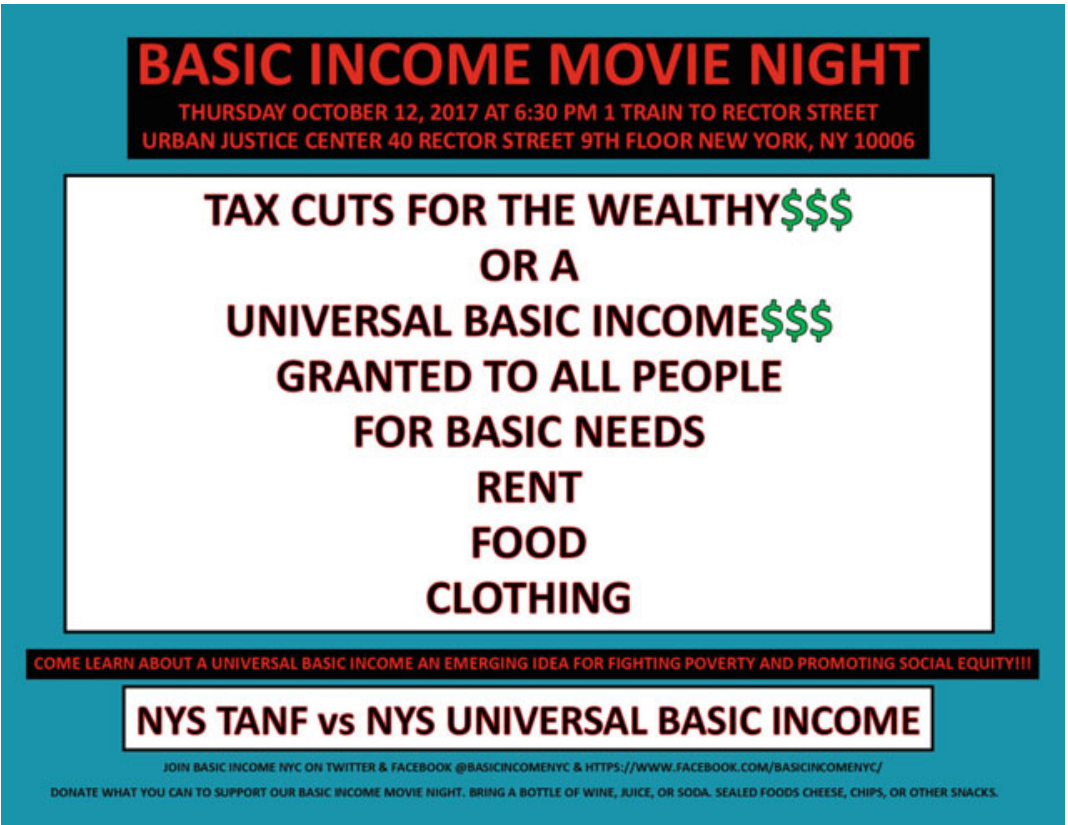

Fig. 6.3 Basic Income Movie Night flyer (Source Image by Wendy O'Shields; Owned by Author)

was until during the introductions he stood up and said, "I'm Andrew, I'm from New York, and I am running for President." People were definitely surprised. His campaign has contributed immeasurably to the pre-existing UBI movement. I was so happy to have a candidate to the Presidency that had thought through UBI and had decided it made sense. Andrew gave me a copy of his book, The War on Normal People. He wrote, "Dear Diane, thank you for being part of the movement for a Universal Basic Income from the very beginning. Let's show them what we can do together. Andrew."

Every month, I was meeting new UBI supporters, writers, and people who wanted to move toward a national UBI. I started following the Poor People's Campaign. They were unifying poor people across the country against racism, militarism and poverty, and the distorted moral narrative of the United States; a Guaranteed Annual Income, or UBI, is part of 


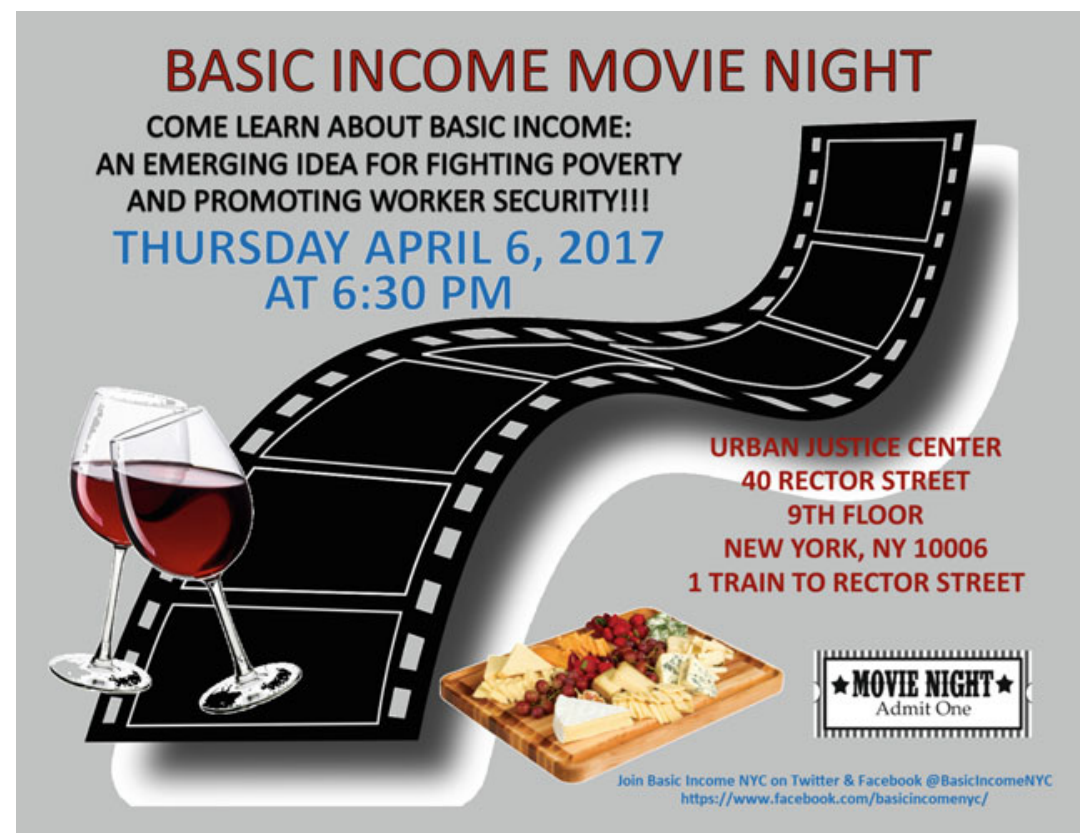

Fig. 6.4 Basic Income Movie Night flyer (Source Image by Wendy O'Shields; Owned by Author)

their demands, as it was when Dr. King led the Poor People's Campaign in 1967-1968. The premature cancellation of the Ontario Basic Income trial begun in the spring of 2017 further galvanized ordinary people in Canada to fight back, and the stories of hardship of the participants following its cancellation were one more event that energized us UBI activists in the United States and elsewhere.

I am an advocate of a Universal Basic Income because it has been a long and tedious battle, fought by many women on welfare, to go state by state trying to push state-run programs to be more adequate and more humane. Writing about the miseries of TANF, as I do, rarely results in improvement to the lives of poor people. We need a national wave of activism. For similar reasons, I have never put my boots on the ground in any "Fight For \$15," though I respect the work of those who do it, and see the value of fair wages. Minimum wage activism reinforces the idea that people need to trade their labor for income in a world where those 
jobs are being automated away. It also does not improve the situation of mothers and other unpaid caregivers, as it does not include this labor in its fight. Minimum wage activists, when successful, only win a few dollars more, in only one place. A UBI will aid the passing of minimum wage laws by providing an alternative assured income stream to people, who can then reject jobs that won't pay a fair wage. We need both.

\section{Basic Income March}

In April of 2019, I got an e-mail from James Felton Keith. He described himself as a Harlem resident running for Congress in NY District 13 and a UBI activist with a radio show out of City College entitled Inclusionism. He said that someone had told him that I was running monthly Basic Income Movie Nights, and that he should talk to me.

Among other things, James sees a UBI as an after-tax profit among stakeholders in a society, a way to "properly distribute equity to the American people." $\mathrm{He}$ also thinks that we derive value from our human relationships, and by extension, if we cultivate human relationships, we should derive economic value for this work. This works for me. Unpaid caregivers are relationship-builders, and these relationships contribute economic value to our society. The first meeting James and I had was at the first New York City rally for Andrew Yang in Washington Square Park. The second was in James's district, Washington Heights. Over the course of a few meetings, we talked about Basic Income Movie Nights, and I expressed how our attendance was dropping as a result of the success of the UBI movement. Our Movie Nights were principally designed to introduce people to UBI in a friendly, social setting where people could freely ask questions and express their thoughts. Now, since more people than ever were aware of UBI, they were less compelled to come to Movie Nights. I said, (a) we needed to hold our Movie Nights in places where far more people still didn't know or had not heard about UBI and (b) we needed to give those who already were committed to a UBI something far more enticing and useful to do than meet people new to it. We decided to have the next Basic Income Movie Night in West Harlem, hosted by a large tenants' association that was already actively fighting the sale of their buildings to a developer. Our Harlem Basic Income Movie Night was a hit. People who had never heard of UBI asked questions, argued with us and argued with each other; just what people need to be doing to be able to decide whether an idea works for them. 
Later that week, James and I met to talk about everything that had gone right. We talked over a beer at a bar in his district. I said, "It was great. We got to talk to dozens of people who were hearing about UBI for the first time and who are active in their communities already and who need a UBI, not people who are just philosophically interested in it."

I said, "You know, I think we should do another meeting. Only I want to have it outside. You know, so even people who weren't planning on coming can see what is going on, and we can give them flyers, rope them in as they walk by."

"We should march," James said.

"That sounds like a lot of work to plan," I said.

"No, it's easy," James said. "Up here there are marches a few times a month."

So we decided to do a Basic Income March. It wasn't easy at all, but in hindsight it is better I didn't know that at the outset. It was exciting. Once we got started, great people jumped on board and there was no turning back. We spent June to October planning the Basic Income March. We quickly and fortunately picked up great people to be part of the team. I wrote a grant request so we could hire people to be our digital team. The Gerald Huff Fund for Humanity provided some support. Stacey Rutland and Dylan Enright came aboard, doing way more work than just our digital campaign. Hawk Newsome, Chairperson of Black Lives Matter of Greater New York and human rights activist, agreed to be emcee for the march. We got organizations to sponsor us. We got permits.

And, most importantly, we got marchers. Dozens of people from USBIG and other Basic Income groups showed up, some from other cities, some from far away. Hundreds of people came to our NYC march, a total of about 700. Alex Howlett came from Boston. Scott Santens came from New Orleans. Karl Widerquist came from Qatar. Conrad Shaw and Deia Schlosberg, who are working on a film about their UBI project, Bootstraps, came from down the street in West Harlem. We had extended a call to UBI supporters in other cities to have marches and provided access to logos, signs, and images that they could adapt. We walked the route and realized that our planned route, from the South Bronx Post Office to West Harlem, was not going to work. The logistics were wrong, and there was a bus stop right there for a half dozen buses that would assure chaos. We found an alternate starting point and went with it, reversing the route to end in the Bronx and start in Manhattan. We 
would walk across West 145th and end in Mott Haven, one of the poorest districts in the United States. We visited the NYPD precincts and got permits.

We had the participation of the Theatre of the Oppressed, a performance troupe that produces original plays that take on issues of human rights, race, poverty, and oppression. They hosted a sign-making party for the march and created a play to be performed at the end point. I am in awe of their work. If we had a Universal Basic Income, they could do more of it.

We asked supporters of Andrew Yang to help us flyer for the march. They showed up wherever we asked them to help. The "Yang Gang" showed up on the day, and we were very happy to have them. The march has also helped to grow the relationship between the older members of the UBI community and the newer, younger members of local Yang Gangs.

In the end, there were thirty marches, all which took place on October 26, 2019, with the exception being San Francisco on October 27th. In New York City, we had an estimated 700 marchers. The all-city total was about 10,000 people. It was inspiring to have Berlin and Amsterdam and Kisumu all marching the same day.

The morning of October 26th, the New York Police Department decided to allow us to march in the roadbed of West 145th street. Marching over the Third Avenue Bridge to the South Bronx was exhilarating, listening to the chants, of " $\$ 1,000$ a month!" Cars drove by honking their horns as we marched into The Bronx to Roberto Clemente Plaza. James Felton Keith, Scott Santens, Andy Stern, Karl Widerquist, Conrad Shaw, and Chivona Newsome spoke to the crowd gathered at the plaza at Third Avenue and 149th street. Five of our speakers had a combined fifty to sixty years of experience working on Universal Basic Income.

Glitches? There were little ones and bigger ones, and we overcame them all. A funny one was having to tell a church full of Andrew Yang supporters that they'd have to remove their MATH hats for a little while. Also, not having four arms to carry all the flyers and signs and a bag I needed to carry along the march route. And in the euphoria that all was moving along well, forgetting to stop to eat.

Also, some organizations that I invited to come march turned me down. Some cited wanting to tread carefully on the UBI issue, because they have heard that some new UBI supporters want UBI to replace current aid programs (Pagen, e-mail communication, September 2, 2019). This idea of removing every aid program if a UBI passes has no legs 
and is a rumor pronounced by faceless people to frighten poor people. I know not one activist nor even one "tech guy" who embraces that idea; but these rumors are hard to shake. That said, I know that people will likely abandon TANF and its invasive behavior requirements and inadequate benefit amounts once they receive UBI, and that would be just fine. It is my hope that as people study UBI and talk to those who need it most, they will feel more confident in becoming activists for UBI. $48 \%$ of Americans support a Universal Basic Income for the United States (Gallup, 2019), and 75\% of Canadians do, and both trends are upward.

My hope is that we can bring everyone around in favor of including income as a right, alongside housing, health care, and education. We produce whether someone is paying us or not. Some of the most valuable work I have done has been done without someone paying me. Having the "right to work" even to work "with dignity" will never amount to much improvement without an income guarantee. An income guarantee assures the ability to walk away from undignified work, a true expression of liberty. It is hard to get my head around declarations that somehow UBImoney without a means test-is a policy that harms poor people. There needs to be more work to get those most in need of income involved in UBI activism, so they can decide for themselves and take part in designing the UBI we need. If we double down on a world where only paid work is work, we are realigning our values to assign less importance to the things no one will pay us to do. Fewer people will be able to produce meaningful things, or help others. Lots more people will be poor, and lots more of us will have bullshit or make work jobs. Not a good scenario.

The next phase of the Basic Income March is being planned over the next few months; several of the Basic Income March organizers across states have created a new organization, Income Movement, which includes not only plans for future marches for a national UBI but other street actions, social media actions, political strategizing, political theater and creativity, and galvanizing communities to apply pressure to their representatives, employing local outlets and people, to win to support UBI legislation. The week of April 24th, activists and people sent 10,000 letters to Congress demanding a UBI in the next COVID-19 pandemicrelated Stimulus, Working together, we got \#CongressPassUBI to trend to \#3 on Twitter. We plan to accelerate and intensify the current movement. We are working together to build a foundation and are preparing to have conversations nationwide to find allies to make us sustainable. 


\section{CONCLUSION}

In conclusion, I want to outline how income solves problems. In the weeks after Hurricane Irene hit New York in August 2011, a gigantic pile of donated clothes grew in the hallways of the various drop-off points, unable to be contained any longer. Local officials took note of the problem and coordinated vehicles to pick up all those clothes and bring them to one place big enough to hold it all: the stadium in the town of Sidney, New York. There they stored the numerous growing piles of socks, shirts, kids' jeans, jackets, sweatshirts, even neckties (who needs a necktie in August in the Northeast). By radio and by signs posted all around the counties, the word was put out that anyone needing clothing should go to Sidney stadium. But the demand for clothing wasn't nearly as big as the pile. Finally, after many months of costly storage and expended effort, the gigantic pile of donated clothing that grew out of the 2011 floods was hauled out of Sidney stadium in trucks and disposed of in an upstate landfill. Had the residents been given income instead, the whole sad, embarrassing affair would have been avoided.

And so it goes. Money is not just money-it is the power to act to save your loved ones. The parents of Scylee and Ibanez Ambrose, the girls who died in 2016 in the NYC shelter, needed a Universal Basic Income; with it, these parents would have been able to leave the place New York City had them staying. They could have paid for something safer, a real home, instead of the shelter that killed their children. Kimberly Dobbie, the mother in Maine stabbed to death because when her state did not provide cash assistance, she had to accept help from a stranger, could have met her children's needs with her own money if her country had a Universal Basic Income. The 140 million poor and low-income Americans (Institute for Policy Studies 2018) who are expected to live without money, also need a Universal Basic Income. Currently, the U.S. has no cohesive and adequate social welfare policy, because it refuses to distribute income. The assemblage of private annual food drives, coat drives, and toy drives, housing "lotteries," and means tested cash pegged far below a living income are not social welfare policy.

Universal Basic Income will consign these terrible injustices, mistreatment, malnourishment, and deaths by poverty to the past. Fifteen years in social work and UBI activism has been more than enough to convince me of this. For all those who say we need to spend another few years studying UBI “to make sure it doesn't harm poor people," take 
note that, when the "Welfare Reform" wave of 1996 cut families off of welfare, capped benefits to a family even when more children were born, and when states made babies spend all day in daycare at as young as one month old, nobody studied those changes first to make sure no poor people got hurt. Universal Basic Income is going to save families, not harm them. It is going to give them the power to say no to the indignities and coercion of the current welfare system. For programs like TANF to remain relevant, states will have to overhaul them to actually be useful.

We have already made great gains in awareness of UBI. Furthermore, thanks to the recent attention brought to UBI by Andrew's run in the 2020 presidential cycle, new writing and media coverage of UBI, and the cancelled Ontario Basic Income trial that is now a lawsuit (Houser 2019), as well as our historic 2019 Basic Income March(es), we know we have enough people for this movement. The catastrophic blow to the existing system of income through waged work brought on by the COVID-19 pandemic has accelerated the UBI movement even more. By intensifying our activism, presenting new members of the UBI community to run for office, and cooperating across communities to design an effective and just UBI, we can avoid more suffering. Our national anti-poverty program is no more than a slush fund to benefit states, not people; it is social engineering, perpetrated mostly on mothers of young children, masquerading as income support. It exacts labor from people in need. Instead of helping, it fuels social problems including depression, addiction, malnourishment and homelessness, and it is a public health and humanitarian crisis. We'll stop the crisis by making a national Universal Basic Income a reality.

\section{REFERENCES}

Administration for Children and Families. (2018). "TANF Caseload Data 2018." https://www.acf.hhs.gov/ofa/resource/tanf-caseload-data-2018.

Center for Budget and Policy Priorities. 2018. "State Fact Sheets: Trends in State TANF-to-Poverty Ratios," November 28. http://www.cbpp.org/research/ family-income-support/state-fact-sheets-trends-in-state-tanf-to-poverty-ratios.

City of New York. n.d. "Contract Details for Bushwick Economic Development Corporation." https://www.checkbooknyc.com/smart_search?search_ term $=$ Bushwick\%2BEconomic\%2BDevelopment\%2BCorporation.

Funiciello, Theresa. 1993. Tyranny of Kindness: Dismantling the Welfare System to End Poverty in America. New York: Atlantic Monthly Press. 
Funiciello, Theresa, and Diane Pagen. 2006. The Adventures of Carrie Giver: The Cost of Caring. New York: TR Rose Associates.

Germanis, Peter. 2019. "TANF Just Received the Golden Fleece Award! WellDeserved, But Who Should Get Credit: HHS or Congress?" July 31. Accessed August 20, 2019. https://mlwiseman.com/wp-content/uploads/2019/08/ Hill.pdf.

Gil, David. 1981. Unravelling Social Policy. Vermont: Schenkman Books.

Glazer, Sarah. 2017. “UBI: Would Cash Payments Relieve Job Losses?” CQ Researcher, September 8.

Houser, Kristin. 2019. "Canadians Sue Ontario for Cancelling Its Basic Income Trial." Futurism, March, 29. https://futurism.com/the-byte/ontariolawsuit-basic-income-project.

Institute for Policy Studies. 2018. "The Souls of Poor Folk: Auditing America 50 Years After the Poor People's Campaign." https://www. poorpeoplescampaign.org/wp-content/uploads/2019/12/PPC-Audit-Full410835a.pdf.

King, Rev. Dr. Martin Luther. 1967. Chaos or Community? Where Do We Go from Here? New York: Beacon Press.

Lewis, Michael A., and Karl Widerquist. 2002. Economics for Social Workers. New York: Columbia University Press.

Mecia, Tony. (2018). "The Case for Free Money." The Washington Examiner, February 10. https://www.washingtonexaminer.com/weekly-standard/thecase-for-free-money.

Metz, Holly. 2017. Killing the Poormaster: The Depression Era Murder That Put America's Welfare System on Trial. Chicago: Chicago Review Press.

Pagen, Diane. 2010. "Missing from the First Lady's Fat Crusade: Cost." New York Daily News, March 17.

Pagen, Diane. 2017. "Our Grenfell: Slow Death of the Poor." New York Daily News, July 9. https://www.acf.hhs.gov/sites/default/files/ofa/2017_ recipient_tan.pdf.

Personal Responsibility and Work Opportunity Reconciliation Act of 1996. Public law 104-193. 104 USC section 2105, October 28, 2019. https:// www.congress.gov/104/plaws/publ193/PLAW-104publ193.pdf.

Reinhart, R. J. 2019. "Universal Basic Income Favored in U.K., Canada, But Not U.S." Gallup News, September 30. Accessed January 20, 2020. https://news. gallup.com/poll/267143/universal-basic-income-favored-canada-not.aspx. 